\title{
Evaluation of real-time PCR targeting the lipL32 gene for diagnosis of Leptospira infection
}

\author{
Daša Podgoršek ${ }^{1}$, Eva Ružić-Sabljić ${ }^{1}$, Mateja Logar ${ }^{2}$, Andrea Pavlović ${ }^{3}$, Tatjana Remec ${ }^{4}, Z^{2}$ vonko Baklan ${ }^{5}$,
} Emil Pal ${ }^{6}$ and Tjaša Cerar ${ }^{1 *}$ (D)

\begin{abstract}
Background: Different diagnostic methods have been used for the laboratory confirmation of leptospirosis. Molecular diagnostic techniques are not only faster and more sensitive than culture analysis, but can also detect a Leptospira infection before the appearance of antibodies. The aim of the present study was to analyze and compare two different PCR approaches applied to blood and urine specimens obtained from patients with clinical manifestations that were suggestive of leptospirosis. Furthermore, the results of these different PCR approaches were compared with the results of culture and serology analyses.

Results: A total of 400 samples (234 blood or $58.5 \%$ and 166 urine of $41.5 \%$ ) from 310 Slovenian patients with clinical manifestations suggestive of leptospirosis were tested using conventional PCR assays targeting the rrs gene and RT-PCR targeting the lipL32 gene. Additionally, culture, serology and sequence analysis were performed for the majority of these samples. The PCR and RT-PCR results were concordant in 376 out of 400 of these samples (94.0\%). Conventional PCR was positive for 27 out of 400 samples (6.8\%) and RT-PCR was positive for 47 out of 400 samples (11.8\%). Culture and microscopic agglutination tests supported these diagnoses.
\end{abstract}

Conclusions: A comparison of the two PCR methods indicated that the RT-PCR targeting of the lipL32 gene was faster, more sensitive and more specific for the determination of Leptospira DNA in these clinical samples.

Keywords: Leptospira, PCR, Lipl32, Leptospirosis

\section{Background}

Leptospirosis is an acute febrile zoonotic disease that is caused by spirochetes bacteria of the genus Leptospira. This disease is prevalent in tropical and subtropical regions, and has been reported in other parts of the world $[1,2]$. In Slovenia, leptospirosis is endemic in the most eastern region of the country, known as Pomurje. Indeed, up to 30 cases per year of Leptospira infection are reported in Slovenia [3].

\footnotetext{
* Correspondence: tjasa.cerar@mf.uni-li.si

${ }^{1}$ Institute of Microbiology and Immunology, Faculty of Medicine, University of Ljubljana, Zaloška 4, SI-1000 Ljubljana, Slovenia

Full list of author information is available at the end of the article
}

Rodents constitute the main carrier of Leptospira, although many other free-living and domesticated animals can also become infected. These bacteria are excreted in the urine of infected animals, and can thus contaminate fields, meadows, and standing and running water. Leptospira infection in humans can arise from direct contact with an infected animal or from indirect contact with a contaminated environment. In Slovenia, the risk of acquiring leptospirosis is associated with occupational and recreational exposure [3].

Leptospirosis can seen in forms ranging from mild influenza-like symptoms to severe jaundice, renal failure and bleeding, and can result in the death of the patient

(c) The Author(s). 2020 Open Access This article is licensed under a Creative Commons Attribution 4.0 International License, which permits use, sharing, adaptation, distribution and reproduction in any medium or format, as long as you give appropriate credit to the original author(s) and the source, provide a link to the Creative Commons licence, and indicate if changes were made. The images or other third party material in this article are included in the article's Creative Commons licence, unless indicated otherwise in a credit line to the material. If material is not included in the article's Creative Commons licence and your intended use is not permitted by statutory regulation or exceeds the permitted use, you will need to obtain permission directly from the copyright holder. To view a copy of this licence, visit http://creativecommons.org/licenses/by/4.0/. The Creative Commons Public Domain Dedication waiver (http://creativecommons.org/publicdomain/zero/1.0/) applies to the data made available in this article, unless otherwise stated in a credit line to the data. 
$[1,4]$. The clinical diagnosis of Leptospira infection can also be confused with other febrile illnesses due to the similarity of clinical symptoms [1,3-5]. The early diagnosis of Leptospira and subsequent antimicrobial therapy are thus very important for both clinicians and patients in order to reduce patient mortality and morbidity.

Different diagnostic methods have been described for the confirmation of leptospirosis $[1,4,6]$. Serological tests based on the presence of specific antibodies against Leptospira are typically used in routine diagnosis. The main problem here is that the antibodies became detectable from one to 2 weeks after clinical presentation, or even later, which is too late for early antibiotic treatment. Instead, the microscopic agglutination test (MAT) is considered the reference test for leptospirosis $[4,6]$. The culturing of samples is also a reliable method, but is time consuming and has low sensitivity $[1,6,7]$. In contrast, molecular diagnostic techniques (e.g., polymerase chain reaction [PCR]) are faster and appear to be more sensitive than culturing, and can detect Leptospira directly in specimens $[4,8,9]$. Thus, PCR can confirm infection earlier than serological tests. More recently, the development of real-time (RT-)PCR was a revolution for the molecular diagnosis of infectious diseases. RT-PCR also has several advantages over conventional PCR, as it is easier to perform and less time consuming, shows reduced variability and contamination, facilitates online monitoring, and does not require post-reaction analyses $[9,10]$.

Several RT-PCR assays that amplify different target sequences have been described for the diagnosis of Leptospira infection $[4,8,9,11-15]$. The majority of these studies have indicated a primary role for the lipL32 gene, which encodes the Leptospira subsurface lipoprotein Lipl32 [16] . Because Lipl32 is believed to be a virulence factor that is only presented in pathogenic species, this provides for the selective detection of the pathogenic Leptospira and helps to increase the specificity of these methods $[17,18]$.

The aim of the present study was to analyze and compare two different PCR approaches applied to blood and urine specimens obtained from patients with clinical manifestations that were suggestive of leptospirosis.
Furthermore, the results of these different PCR approaches were compared with the results of culture and serology analyses.

\section{Results}

To detect Leptospira DNA in blood and urine samples of patients with clinically suspected leptospirosis, two PCR approaches were used that amplified two different target DNA sequences: the rrs and lipL32 genes. In addition to these molecular tests, culture and MAT were performed on samples from the majority of the patients.

This study included 400 specimens of blood $(n=234)$ and urine $(n=166)$ from 310 patients with suspected Leptospira infections. Both blood and urine specimens were received from 66 of the 310 patients, while only one type of sample (i.e. blood or urine) for the rest of the patients (224 our of 310) was referred to the analysis laboratory. Thus, including these together, there were 66 blood-urine paired specimens, and 168 single blood samples and 100 single urine samples, from 310 different patients from different hospitals in Slovenia.

The conventional PCR that targeted the rrs gene gave positive result in 27 out of 400 samples $(6.8 \%)$, while the RT-PCR that targeted the lipL32 gene was positive in 47 out of 400 samples $(11.8 \%)$. This difference was statistically significant $(p=0.0001)$. The results from each PCR and comparisons of the two tests are given in Table 1 . These results across both tests were consistent in 376 out of 400 cases $(94.0 \%)$, with 25 samples positive and 351 samples negative with both of these assays (Table 1).

Using the RT-PCR with these blood and urine samples, 31 out of 234 samples (13.2\%) and 16 out of 166 samples $(9.6 \%)$ were positive, respectively, compared to conventional PCR reactions with 16 out of 234 positive samples $(6.8 \%)$ and 11 out of $166(6.6 \%)$ positive samples, respectively (Table 1). These differences between the positive results for the two PCR protocols reached significance in the case of blood samples $(p=0.0003)$, but not for urine $(p=0.1824)$. These two PCR tests were simultaneously positive in 16 out of $234(6.8 \%)$ cases and 9 out of 166 cases (3.8\%), respectively (Table 1$)$.

Table 1 Results for the detection of leptospiral DNA using conventional PCR and RT-PCR across 400 samples of either blood or urine

\begin{tabular}{|c|c|c|c|c|c|c|c|c|c|}
\hline \multirow{3}{*}{$\begin{array}{l}\text { Conventional } \\
\text { PCR }\end{array}$} & \multicolumn{9}{|l|}{ RT PCR } \\
\hline & \multicolumn{3}{|l|}{ Blood } & \multicolumn{3}{|l|}{ Urine } & \multicolumn{3}{|c|}{ Blood \& Urine } \\
\hline & Pos (\%) & Neg (\%) & All (\%) & Pos (\%) & Neg (\%) & All & Pos (\%) & Neg (\%) & All \\
\hline Pos & $16(6.8)$ & 0 & $16(6.8)$ & $9(5.4)$ & $2(1.2)$ & $11(6.6)$ & $25(6.3)$ & $2(0.5)$ & $27(6.8)$ \\
\hline Neg & $15(6.4)$ & $203(86.8)$ & 218 (93.2) & $7(4.2)$ & $148(89.2)$ & 155 (93.4) & $22(5.5)$ & $351(87.7)$ & $373(93.2)$ \\
\hline All & $31(13.2)$ & $203(86,8)$ & $234(100)$ & $16(9.6)$ & $150(90.4)$ & $166(100)$ & $47(11.8)$ & $353(88.2)$ & $400(100)$ \\
\hline $\mathrm{p}$ (Chi sq) & 0.0003 & & & 0.1824 & & & 0.0001 & & \\
\hline Kappa & 0.6492 & & & 0.6383 & & & 0.6453 & & \\
\hline
\end{tabular}


Table 2 lists all of the patients where positivity was seen for at least one of the two PCR assays, along with results from culture and/or serology analyses. The results of the sequence analysis on the products of some of the positive conventional PCRs are also reported (Table 2).

Among 66 of the 310 patients who provided paired blood-urine samples for PCR testing, five patients were blood and urine positive for Leptospira according to both PCR protocols (Table 2; patients \#1, \#16, \#23, \#24 and \#34) and one patient was only blood and urine positive according to the RT-PCR (Table 2, patient \#20), while one patient was blood positive according to both tests, but only showed urine positivity according to the RT-PCR (Table 2; patient \#41). In four of these 66 patients, Leptospira infection was also confirmed using other diagnostic methods (i.e. culture and MAT) and/or by the sequence analysis of conventional PCR products (Table 2; patients \#1, \#16, \#20 and \#24). A large majority of the patients whose paired blood-urine samples were simultaneously sent to the laboratory were PCR negative for both of these PCR protocols (59 out of 66).

It is evident from Table 1 that 25 samples were positive for both PCR protocols, and that these samples belonged to 20 out of 310 patients. Six of these patients with paired blood-urine samples are mentioned above (Table 2; patients \#1, \#16, \#23, \#24, \#34 and \#41, with the exception of a urine sample). In the remaining 14 of these patients, leptospirosis was confirmed using additional diagnostic assays. Of these 10 patients, three were culture- and MAT-positive (Table 2; patients \#3, \#18 and \#39), one was culture positive, but MAT-negative (Table 2; patient \#33) and three were MAT-positive, but culture negative (Table 2; patients \#4, \#7 and \#38). The sequence analysis of the conventional PCR amplicons of three of the culture and MAT-negative patients showed evidence of Leptospira DNA (Table 2; patients \#12, \#27 and \#36).

Table 1 also shows that 22 out of 400 samples (5.5\%) from 21 patients were negative according to conventional PCR, but positive according to RT-PCR. Three of these samples belonged to two patients, who are mentioned above (Table 2; patients \#20 and \#41). Culture, MAT and sequence analyses were performed to confirm these as Leptospira infections for the majority of the remaining 19 patients. Leptospirosis was confirmed in 16 of these 19 patients: one out of 16 was culture- and MAT-positive (Table 2; patient \#15), three out of 16 were culture positive (Table 2 ; patients \#17, \#30 and $\# 32$ ) and 10 out of 16 patients were MAT-positive (Table 2; patients \#5, \#8, \#11, \#14, \#25, \#26, \#29, \#31, $\# 37$ and \#40). The PCR products were sequenced for two out of 16 patients where culture and MAT analyses were negative or were not performed (Table 2; patients $\# 13$ and \#22), while a nucleotide sequence analysis showed the presence of Leptospira in both cases. In three out of 19 patients (Table 2; patients \#9, \#21 and \#28), Leptospira infection was not confirmed using other diagnostic methods, or other diagnostic methods were not applied.

On the other hand, two out of 310 patients (0.7\%) were positive according to conventional PCR and negative using RT-PCR (Table 3), as samples that originated from urine. Both of these patients were culture- and MAT-negative (Table 2; patients \#10 and \#42). The sequence analysis showed identity to Atopobium vaginae for one of these samples, which suggests false positive results with conventional PCR, while Leptospira was confirmed in the other sample.

As indicated, a sequence analysis was performed on PCR amplicons obtained from the conventional PCR approach (as three reactions per set). Leptospira DNA was confirmed in 11 samples from eight patients whose final result was positive (Table 2 ; patients \#1, \#10, \#12, \#16, $\# 24$, \#27, \#33 and \#36), and in seven samples from seven patients whose final result was negative (Table 2; patients \#13, \#15, \#17, \#22, \#25, \#26 and \#37). Moreover, there was a sample with a positive final result using conventional PCR where the sequence analysis did not confirm the presence of Leptospira DNA (Table 2, patient \#42).

Taken together, the RT-PCR that was based on amplification of the lipL32 gene was significantly more sensitive than the traditional PCR that was based on amplification of the rrs gene $(p=0.0001)$. Culture analyses were performed for 34 out of 42 patients who were positive according to at least one of the two PCR assays (Table 2), where 8 out of 42 patients (19.1\%) were culture positive. It is evident from Table 2 that culture analyses were always simultaneously positive with the other microbiological tests performed. MAT analyses were performed for 38 out of 42 patients who were positive according to at least one of the two PCR protocols (Table 2), with 20 out of 42 of these patients (47.6\%) being MAT-positive. It can be seen from Table 2 that MAT analyses were simultaneously positive with RTPCR for a larger majority of patients.

\section{Discussion}

Suspicion of leptospirosis is based on epidemiological data, and patient clinical symptoms and signs. As the clinical characteristics of leptospirosis can be confused with other infections, this highlights the great importance of the laboratory diagnosis of these infections $[1,4$, 5]. Due to the low sensitivity of culture analyses and the delayed appearance of antibodies (i.e. 2 weeks or more after the onset of symptoms), molecular approaches are welcome for the early microbiological diagnosis of Leptospira infection $[4,6,7,9]$. The detection of Leptospira 
Table 2 Patients (Pt) who were positive according to at least one of the three conventional PCR assays or according to RT-PCR, including results from conventional PCR product sequence analysis, and from culture and serology (i.e. microscopic agglutination test [MAT] on blood) analyses

\begin{tabular}{|c|c|c|c|c|c|c|c|c|c|}
\hline \multirow[t]{2}{*}{ Pt } & \multirow[t]{2}{*}{ Sample } & \multicolumn{5}{|c|}{ Conventional PCR } & \multirow{2}{*}{$\begin{array}{l}\text { RT- } \\
\text { PCR }\end{array}$} & \multirow[t]{2}{*}{ Culture } & \multirow[t]{2}{*}{ MAT } \\
\hline & & LeptoA/B & $\mathrm{L} 3 / 4$ & L4/ LPato2 & Final result & Product sequence analysis & & & \\
\hline 1 & blood & $\operatorname{pos}^{a}$ & neg & $\operatorname{pos}^{a}$ & pos & a Leptospira interrogans & pos & neg & \\
\hline 1 & urine & $\operatorname{pos}^{a}$ & neg & $\operatorname{pos}^{a}$ & pos & aLeptospira interrogans & pos & neg & $\begin{array}{l}1600 \\
\text { Sejroe }\end{array}$ \\
\hline 2 & urine & pos & neg & pos & pos & NT & pos & neg & neg \\
\hline 3 & urine & pos & neg & pos & pos & NT & pos & pos & $\begin{array}{l}\text { Pos } \\
1600 \\
\text { Icterohaemorrhaiae }\end{array}$ \\
\hline 4 & urine & pos & neg & pos & pos & NT & pos & neg & $\begin{array}{l}\text { Pos } \\
600 \\
\text { Australis }\end{array}$ \\
\hline 5 & blood & neg & neg & neg & neg & NT & pos & neg & $\begin{array}{l}\text { Pos } \\
25,600 \\
\text { Cynopteri }\end{array}$ \\
\hline 6 & blood & pos & neg & pos & pos & NT & pos & neg & neg \\
\hline 7 & blood & pos & neg & pos & pos & NT & pos & neg & $\begin{array}{l}\text { Pos } \\
100 \\
\text { Australis }\end{array}$ \\
\hline 8 & blood & neg & neg & neg & neg & NT & pos & neg & $\begin{array}{l}\text { Pos } \\
102,400 \\
\text { Tarassovi }\end{array}$ \\
\hline 9 & blood & neg & neg & neg & neg & NT & pos & neg & neg \\
\hline 10 & urine & $\operatorname{pos}^{a}$ & neg & $\operatorname{pos}^{a}$ & pos & a Leptospira kirschneri & neg & neg & neg \\
\hline 11 & blood & neg & neg & neg & neg & NT & pos & neg & $\begin{array}{l}\text { Pos } \\
1600 \\
\text { Sejroe }\end{array}$ \\
\hline 12 & blood & $\operatorname{pos}^{a}$ & neg & $\operatorname{pos}^{a}$ & pos & aLeptospira spp. & pos & neg & Neg \\
\hline 13 & urine & neg & neg & $\operatorname{pos}^{a}$ & neg & a Leptospira spp. & pos & NT & Neg \\
\hline 14 & blood & neg & neg & neg & neg & NT & pos & neg & $\begin{array}{l}\text { Pos } \\
800 \\
\text { Australis }\end{array}$ \\
\hline 15 & blood & neg & neg & $\operatorname{pos}^{a}$ & neg & a Leptospira interogans & pos & pos & $\begin{array}{l}\text { Pos } \\
200 \\
\text { Canicola }\end{array}$ \\
\hline 16 & blood & $\operatorname{pos}^{a}$ & neg & $\operatorname{pos}^{a}$ & pos & a'Leptospira spp. & pos & neg & neg \\
\hline 16 & urine & $\operatorname{pos}^{a}$ & neg & $\operatorname{pos}^{a}$ & pos & a'Leptospira spp. & pos & neg & neg \\
\hline 17 & blood & neg & neg & $\operatorname{pos}^{a}$ & neg & a'Leptospira spp. & pos & pos & NT \\
\hline 18 & blood & pos & neg & pos & pos & NT & pos & pos & $\begin{array}{l}\text { Pos } \\
400 \\
\text { Grippotyphosa }\end{array}$ \\
\hline 19 & blood & pos & neg & pos & pos & NT & pos & NT & neg \\
\hline 20 & blood & neg & neg & neg & neg & NT & pos & neg & Pos \\
\hline 20 & urine & neg & neg & neg & neg & NT & pos & neg & $\begin{array}{l}200 \\
\text { Australis }\end{array}$ \\
\hline 21 & blood & neg & neg & neg & neg & NT & pos & NT & NT \\
\hline 22 & blood & neg & neg & $\operatorname{pos}^{a}$ & neg & aLeptospira spp. & pos & NT & NT \\
\hline 23 & blood & pos & neg & pos & pos & NT & pos & NT & neg \\
\hline 23 & urine & pos & neg & pos & pos & NT & pos & NT & \\
\hline 24 & urine & $\operatorname{pos}^{a}$ & neg & $\operatorname{pos}^{a}$ & pos & a Leptospira meyeri & pos & pos & Pos \\
\hline 24 & blood & $\operatorname{pos}^{a}$ & neg & $\operatorname{pos}^{a}$ & pos & aleptospira meyeri & pos & pos & $\begin{array}{l}400 \\
\text { Sejroe }\end{array}$ \\
\hline
\end{tabular}


Table 2 Patients (Pt) who were positive according to at least one of the three conventional PCR assays or according to RT-PCR, including results from conventional PCR product sequence analysis, and from culture and serology (i.e. microscopic agglutination test [MAT] on blood) analyses (Continued)

\begin{tabular}{|c|c|c|c|c|c|c|c|c|c|}
\hline \multirow[t]{2}{*}{ Pt } & \multirow[t]{2}{*}{ Sample } & \multicolumn{5}{|c|}{ Conventional PCR } & \multirow{2}{*}{$\begin{array}{l}\text { RT- } \\
\text { PCR }\end{array}$} & \multirow[t]{2}{*}{ Culture } & \multirow[t]{2}{*}{ MAT } \\
\hline & & LeptoA/B & L3/4 & L4/ LPato2 & Final result & Product sequence analysis & & & \\
\hline 25 & blood & neg & neg & $\operatorname{pos}^{a}$ & neg & aLeptospira spp. & pos & NT & $\begin{array}{l}\text { Pos } \\
200 \\
\text { Grippotyphosa }\end{array}$ \\
\hline 26 & blood & neg & neg & $\operatorname{pos}^{a}$ & neg & aLeptospira spp. & pos & neg & $\begin{array}{l}\text { Pos } \\
200 \\
\text { Australis }\end{array}$ \\
\hline 27 & blood & $\operatorname{pos}^{a}$ & neg & $\operatorname{pos}^{a}$ & pos & a'Leptospira spp. & pos & neg & neg \\
\hline 28 & urine & neg & neg & neg & neg & NT & pos & neg & neg \\
\hline 29 & blood & neg & neg & neg & neg & NT & pos & neg & $\begin{array}{l}\text { Pos } \\
3200 \\
\text { Copenhageni }\end{array}$ \\
\hline 30 & blood & neg & neg & neg & neg & NT & pos & pos & neg \\
\hline 31 & urine & neg & neg & neg & neg & NT & pos & neg & $\begin{array}{l}\text { Pos } \\
400 \\
\text { Panama }\end{array}$ \\
\hline 32 & blood & neg & neg & neg & neg & NT & pos & pos & NT \\
\hline 33 & blood & $\operatorname{pos}^{\mathrm{a}}$ & neg & $\operatorname{pos}^{a}$ & pos & aLeptospira interogans & pos & pos & neg \\
\hline 34 & blood & pos & neg & pos & pos & NT & pos & neg & neg \\
\hline 34 & urine & pos & neg & pos & pos & NT & pos & neg & \\
\hline 35 & blood & pos & neg & pos & pos & NT & pos & neg & neg \\
\hline 36 & blood & $\operatorname{pos}^{a}$ & neg & $\operatorname{pos}^{a}$ & pos & aLeptospira spp. & pos & neg & neg \\
\hline 37 & urine & neg & neg & $\operatorname{pos}^{\mathrm{a}}$ & neg & aLeptospira spp. & pos & neg & $\begin{array}{l}\text { Pos } \\
3200 \\
\text { Sejroe }\end{array}$ \\
\hline 38 & urine & pos & neg & pos & pos & NT & pos & neg & $\begin{array}{l}\text { Pos } \\
800 \\
\text { Grippotyphosa }\end{array}$ \\
\hline 39 & blood & pos & neg & pos & pos & NT & pos & pos & $\begin{array}{l}\text { Pos } \\
1600 \\
\text { Icterohaemorrhaiae }\end{array}$ \\
\hline 40 & urine & neg & neg & neg & neg & NT & pos & neg & $\begin{array}{l}\text { Pos } \\
200 \\
\text { Australis }\end{array}$ \\
\hline 41 & blood & pos & neg & pos & pos & NT & pos & neg & neg \\
\hline 41 & urine & neg & neg & neg & neg & NT & pos & neg & \\
\hline 42 & urine & $\operatorname{pos}^{a}$ & neg & $\operatorname{pos}^{a}$ & pos & ${ }^{\mathrm{a}}$ Atopobium vaginae & neg & neg & neg \\
\hline
\end{tabular}

NT not tested

${ }^{\text {a }}$ Conventional PCR products subjected to sequence analysis

DNA in the first few days of infection facilitates early antibiotic treatment, and thus promotes successful recovery for these patients $[4,8]$. For this reason, molecular diagnosis plays an important role in the treatment of patients with leptospirosis all over the world, including in Slovenia. The present study was designed to compare two different PCR approaches (i.e. conventional PCR and RT-PCR) in patients with clinical manifestations that were suggestive of leptospirosis, and to compare the results of these two PCR approaches with the results of culture and serology analyses.
Different molecular approaches based on different target sequences, molecular methods and study design can be found in literature $[4,8,9,11-15]$. In recent years, several RT-PCR assays have been described $[9,10]$. In the present study, we evaluated a RT-PCR protocol that targets the lipL32 gene, which has high sequence conservation and is the most copious Leptospira protein (i.e. 38,000 copies per cell), thus supporting lipL32 as an appropriate target sequence $[17,18]$. The results of lipL32 RT-PCR assays were compared with results using conventional PCR according to three conventional PCR 
Table 3 Primers and probe sequences for polymerase chain reactions (PCR) performed in the study

\begin{tabular}{|c|c|}
\hline Primer & Sequence \\
\hline L3 & $5^{\prime}$ - TgA ggg TTA AAA CCC CCA AC - 3' \\
\hline$\llcorner 4$ & $5^{\prime}$ - gAT TाT TCg ggT AAA gAT T - 3’ \\
\hline LeptoA & $5^{\prime}-g g C$ gCg TCT TAA ACA Tg - 3' \\
\hline LeptoB & $5^{\prime}-$ TTC CCC CCA TTg AgC AAg ATT - 3' \\
\hline LPato2 & $5^{\prime}$ - TCA CAT Y gCT TAT TTT - 3' \\
\hline LipL32-45F & $5^{\prime}-$ AAg CAT TAC CgC Tg Tgg Tg - 3' \\
\hline LipL32-286R & $5^{\prime}-$ gAACTCCCATTTCAgCgATT - 3' \\
\hline Probe LipL32-189P & $5^{\prime}-$ LC610-AAA gCC Agg ACA AgC gCC g--BHQ2-3' \\
\hline
\end{tabular}

reactions (i.e. LeptoA/B, L3/L4, L4/LPato2) that targeted various regions of the $r$ rs gene that are highly conserved throughout the bacterial kingdom. This study also included culture analyses and serological MAT tests to confirm leptospirosis.

Comparisons of the results of both of these PCR tests showed higher sensitivity for the RT-PCR, as RT-PCR confirmed leptospiral infection in 22 samples (from 21 patients), while traditional PCR revealed negative results for all of these patients. Using two-tailed McNemar tests, the differences between the results of these tests were statistically significant $(p=0.0001)$.

The specificity of the PCR amplicon in the conventional PCR approach was defined using a sequence analysis. In the present study, the conventional PCR gave one falsepositive result when performed on urine samples (i.e. patient \#42), while the RT-PCR correctly identified the absence of Leptospira DNA in the same urine sample. The explanation for false-positive results might lie in the fact that $r$ rs genes in conventional PCR are usually more prone to unexpected cross-reactivity, especially when performed on urine samples, which can contain bacteria that are part of the normal flora of the genital and urinary tract [15].

On the other hand, there was a case with a positive result for conventional PCR that was confirmed as Leptospira infection through sequence analysis, but where negative results were obtained for RT-PCR, and culture and serology analyses (patient \#10). We believe that the negative result for the RT-PCR was due to the fact that this was performed retrospectively, where the sample had been stored for 4 years. There was thus the possibility of DNA degradation in this sample. The possibility of contamination of the conventional PCR during the analytical procedures can be excluded due to the follow-up working conditions of the technique.

The RT-PCR showed higher rates of positivity when performed on blood samples than for the conventional PCR, which would appear to be because of the lower diagnostic sensitivity of the conventional PCR. This low positivity might be due to low bacteremia in some patients, which can be caused by the presence of specific antibodies in the patient's blood (i.e. nine out of the 15 blood samples that were RT-PCR-positive and conventional PCR-negative were MAT-positive) or by empiric antibiotic treatment. These factors are generally known to decrease the positive results of DNA amplification methods [1].

According to the findings of the present study, this RT-PCR protocol has several advantages over conventional PCR protocols. In particular, it is faster and facilitates the detection of amplified fragments during the process and therefore does not require end-point detection, which is very time consuming and less precise. Furthermore, there is less chance of contamination, as the entire process from amplification of the target region to analysis of the amplified DNA is performed in one tube.

Culture and serological tests were performed in the majority of these patients. Culture analysis is known to be time consuming and show low sensitivity, although it remains a valuable diagnostic method and is the best proof of infection. Moreover, an isolated Leptospira strain can then be typed to identify its serovar, which is of great importance in epidemiological studies. On the other hand, serological tests are the most commonly used diagnostic method for Leptospira, although detectable titers of antibodies in the blood usually appear about 5-10 days after the onset of the disease [6]. In the present study, culture analysis was rarely positive, and when it was, this occurred simultaneously with the other tests performed. This was particularly true of the case with RT-PCR, while there were also a number of MAT-positive patients. In the case of inconclusive results of PCR tests, MAT can significantly contribute to the final diagnosis of a disease. The patients in the present study who lacked other microbiological tests were not classified as Leptospira infections from a clinical point of view, and no additional samples were sent to the laboratory for serology and/or cultivation.

\section{Conclusion}

We compared two different PCR approaches that were supported by culture, MAT and sequence analysis. The RT-PCR targeting of the lipL32 gene was shown to be preferred to conventional PCR targeting of the rrs gene, as it is quicker, easier to perform, less prone to contamination and more sensitive for the determination of Leptospira DNA in these clinical samples. This RT-PCR is also more sensitive than culture analyses and quicker than serological tests [19]. Thus, according to these findings, this RT-PCR protocol represents a useful tool for the rapid microbiological diagnosis of acute leptospirosis.

\section{Methods}

Patients and samples

Samples of blood (in EDTA) and urine were obtained from patients with suspected leptospirosis, and were used 
for molecular diagnosis. A suspected diagnosis of leptospirosis was defined as acute febrile illness with headache, myalgia, arthralgia, meningeal irritation and renopatia. Whole blood samples from patients were used for antibody detection. For some patients, whole blood (in blood culture bottles) and urine (in sterile bottles) were collected aseptically for the analysis and isolation of Leptospira.

The patients were observed in different hospitals in Slovenia from January 2001 to December 2014. All of the clinical specimens were collected during initial patient examinations and were sent to the Institute of Microbiology and Immunology in Ljubljana (Slovenia). Some of these patients $(\sim 20 \%)$ have already been included in an evaluation of an immune-chromatographic (Leptocheck) test for the detection of specific antibodies against Leptospira [20].

\section{Nucleic acid extraction from blood and urine samples}

The blood specimens in EDTA were centrifuged at 200x $g$ for $10 \mathrm{~min}$ and the plasma was sampled for DNA extraction. Urine specimens were centrifuged at $14100 \mathrm{x} g$ for $30 \mathrm{~min}$, the supernatant was removed and the pellets were resuspended with $180 \mu \mathrm{L}$ MagNA Pure Bacteria Lysis Buffer (Roche, Mannheim, Germany) and $20 \mu \mathrm{L}$ proteinase K (Roche, Mannheim, Germany). These samples were then incubated for $\geq 10 \mathrm{~min}$ at $65^{\circ} \mathrm{C}$, and then for $10 \mathrm{~min}$ at $95^{\circ} \mathrm{C}$. The total DNA was then extracted using an automated method on a MagNA Pure Compact apparatus (Roche, Germany), in accordance with the manufacturer's instructions. The extracted DNA was stored at $-20^{\circ} \mathrm{C}$ until testing [21].

\section{PCR amplification}

The samples were analyzed for the presence of Leptospira DNA using two different PCR approaches. To avoid PCR contamination and amplicon carry-over, the samples were processed in separate rooms, with the use of plugged pipette tips. A panel of positive and negative control samples was included in each run to monitor amplification and any potential contamination.
The first approach included three different PCR reactions that targeted different parts of the rrs gene, with these three PCR protocols indicated here as 'conventional PCR'. The first of these amplified the DNA of both pathogenic and nonpathogenic Leptospira spp. (LeptoA/ LeptoB), while the other two conventional PCR protocols followed one another as nested PCR (L3/L4; L4/Lpato2), with the amplification of DNA of the pathogenic Leptospira spp. only. The reactions were performed using the primers and protocols described by Merien et al. [22] and Murgia et al. [23]. The amplified products were analyzed on $1 \%$ agarose gels that were stained with ethidium bromide. Under each of the runs for each of the samples, any of these three PCR reactions might be positive, although a final positive result was only considered when the results of the first LeptoA/LeptoB step and the nested L4/Lpato2 analyses were both positive $[4,8]$.

A further PCR protocol was designed as RT-PCR using primers and a probe that targeted the lipL32 gene. The amplification was performed using a RT-PCR machine (LightCycler; Roche, Germany), while a data analysis was performed using the detection system of the RT-PCR machine $[12,13]$.

The primer sequences and reaction conditions for all of these PCR reactions are given in Tables 3 and 4 .

The analytical sensitivity of the RT-PCR targeting LipL32 gene was determined using 10-fold dilutions of gBlocks (Integrated DNA Technologies Inc., Coralville, IA) fragments ranging from $10^{7}$ to $10^{0}$ copies $/ \mu \mathrm{L}$. All dilutions were tested in triplicate, while a negative control was included in the run. The RT-PCR was able to detect $10^{7}$ to $10^{0}$ copies $/ \mu \mathrm{L}$, while PCR efficiency was 1.981 . Patients' samples were considered positive if the cycle threshold $(\mathrm{Ct})$ value was less than 37.

\section{Sequencing}

About half of the PCR products from the conventional PCR approach underwent sequence analysis, with the aim of confirming the presence of Leptospira DNA in these samples. The PCR products were initially purified

Table 4 Protocols used for conventional PCR and RT-PCR

\begin{tabular}{|c|c|c|c|c|c|c|c|c|c|c|c|c|}
\hline \multirow[t]{3}{*}{ Stage } & \multicolumn{9}{|l|}{ PCR } & \multicolumn{3}{|l|}{ RT-PCR } \\
\hline & \multicolumn{3}{|c|}{ LeptoA/LeptoB } & \multicolumn{3}{|l|}{ L3/L4 } & \multicolumn{3}{|c|}{ L4/LPato2 } & \multirow[b]{2}{*}{$\begin{array}{l}\text { Temp. } \\
\left({ }^{\circ} \mathrm{C}\right)\end{array}$} & \multirow[b]{2}{*}{$\begin{array}{l}\text { Time } \\
\text { (s) }\end{array}$} & \multirow[b]{2}{*}{$\begin{array}{l}\text { Cycles } \\
\text { (n) }\end{array}$} \\
\hline & $\begin{array}{l}\text { Temp. } \\
\left({ }^{\circ} \mathrm{C}\right)\end{array}$ & $\begin{array}{l}\text { Time } \\
(\min )\end{array}$ & $\begin{array}{l}\text { Cycles } \\
\text { (n) }\end{array}$ & $\begin{array}{l}\text { Temp. } \\
\left({ }^{\circ} \mathrm{C}\right)\end{array}$ & $\begin{array}{l}\text { Time } \\
(\min )\end{array}$ & $\begin{array}{l}\text { Cycles } \\
\text { (n) }\end{array}$ & $\begin{array}{l}\text { Temp. } \\
\left({ }^{\circ} \mathrm{C}\right)\end{array}$ & $\begin{array}{l}\text { Time } \\
(\min )\end{array}$ & $\begin{array}{l}\text { Cycles } \\
\text { (n) }\end{array}$ & & & \\
\hline $\begin{array}{l}\text { Initial } \\
\text { denaturation }\end{array}$ & 93 & 3 & 1 & 93 & 3 & 1 & 93 & 3 & 1 & & 600 & \\
\hline Denaturation & 93 & 1 & 35 & 93 & 1 & 35 & 93 & 1 & 35 & 95 & 15 & 45 \\
\hline Annealing & 60 & 1 & & 57 & 1 & & 52 & 1 & & 53 & 10 & \\
\hline Elongation & 72 & 1 & & 72 & 1 & & 72 & 1 & & 72 & 10 & \\
\hline Final elongation & 72 & 9 & 1 & 72 & 9 & 1 & 72 & 9 & 1 & 40 & 30 & 1 \\
\hline Hold & 4 & & & 4 & & & 4 & & & & & \\
\hline
\end{tabular}


(PCR Product Clean-Up; Applied Biosystems, Thermo Fisher Scientific, USA) in accordance with the manufacturer's instructions. The reaction mixture contained $5 \mu \mathrm{L}$ of purified PCR product, $0.5 \mu \mathrm{L}$ of exonuclease I and $1 \mu \mathrm{L}$ of shrimp alkaline phosphatase. These were incubated at $37^{\circ} \mathrm{C}$ for $15 \mathrm{~min}$. The reaction was then stopped by heating to $85^{\circ} \mathrm{C}$ for $15 \mathrm{~min}$ [24].

For sequencing the purified PCR products, the same primers as for the PCR reactions were used. Each $20 \mu \mathrm{L}$ reaction mixture contained $5.0 \mu \mathrm{L}$ of purified PCR product, $8.7 \mu \mathrm{L}$ of deionized RNase/DNase-free $\mathrm{H}_{2} \mathrm{O}, 2.0 \mu \mathrm{L}$ of $\mathrm{Big}$ Dye Terminator v3.1 Cycle Sequencing RR-100 MasterMix (Applied Biosystems, Thermo Fisher Scientific, USA), $3.0 \mu \mathrm{L}$ of Big Dye Terminator v3.1 5x Sequencing Buffer (Applied Biosystems, Thermo Fisher Scientific, USA) and $1.3 \mu \mathrm{L}$ of each primer. Cycle sequencing was performed using initial denaturation at $96^{\circ} \mathrm{C}$ for $1 \mathrm{~min}$, followed by 25 cycles of $10 \mathrm{~s}$ at $96^{\circ} \mathrm{C}, 5 \mathrm{~s}$ at $50^{\circ} \mathrm{C}$ and $4 \mathrm{~min}$ at $60^{\circ} \mathrm{C}$ in a thermal cycler (Veriti; Applied Biosystems, Thermo Fisher Scientific, USA). The sequencing products were purified using purification kits (BigDye XTerminator; Applied Biosystems, Thermo Fisher Scientific, USA) and sequenced on an automated sequencer (ABI-3500; Applied Biosystems, Thermo Fisher Scientific, USA) [25]. The sequences were assembled using the CLC Genomics Workbench 6 (CLC Bio, Qiagen, Germany) and analyzed using Ribosomal Database Project sequence matching (http://rdp.cme.msu.edu/seqmatch/seqmatch_intro.jsp).

\section{Microscopic agglutination test}

The blood for antibody detection was collected by venepuncture during initial patient examinationss and was allowed to clot. After centrifugation at $5000 \times g$ for $10 \mathrm{~min}$, the sera were collected and stored at $-20^{\circ} \mathrm{C}$ until testing. The sera were examined using the MAT, with a panel of 15 serovars: Gryppotyphosa, Canicola, Sejroe, Pomona, Cynopteri, Copenhageni, Patoc, Australis, Autumnalis, Pyrogenes, Bataviae, Tarassovi, Castellanis, Panama and Javanica, as reported to be suitable for the geographic area [6]. The sera to be tested were diluted serially and live Leptospira antigen suspensions from a battery of 15 serovars were added. The serum/ Leptospira culture mixtures were incubated at $37^{\circ} \mathrm{C}$ for $1 \mathrm{~h}$ and then examined under dark-field microscopy for Leptospira agglutination, and the titers were determined. Titers of $\geq 100$ were deemed positive $[4,6]$.

\section{Leptospira isolation}

Approximately $1 \mathrm{~mL}$ of each sample (i.e. whole blood or urine) was inoculated into a tube containing $7 \mathrm{~mL}$ of Ellinghausen-McCullough-Johnson-Harris liquid medium, with more than one tube inoculated per sample. The tubes were incubated at $28^{\circ} \mathrm{C}$ for 9 weeks and then examined for Leptospira growth once a week, using dark-field microscopy $[6,7]$.

\section{Statistical analysis}

To compare the performance of the two PCR methods, the kappa value and McNemar's chi-square value were calculated using an Epitools epidemiological calculator [26].

\section{Abbreviations}

MAT: Microscopic agglutination test; RT-PCR: Real-time polymerase chain reaction

\section{Acknowledgements \\ The authors want to thank the staff and patients at all participating hospitals and Christopher Berrie for editing a draft of this manuscript.}

\section{Authors' contributions}

DP, ERS and TC designed the study, performed a literature search and wrote the manuscript. AP, TR, ZB, EP, ML conducted clinical data gathering. DP and TC performed the majority of microbiological analyses. DP, ERS and TC performed data interpretation. All authors have seen and approved the manuscript.

\section{Funding}

This study was supported by the Ministry of Higher Education, Science and Sport of Slovenia (grant no. P3-0083). The party providing funding played no role in study design, data collection and interpretation, or the decision to submit the work for publication.

\section{Availability of data and materials}

The data that support the findings of this study are available from the corresponding author (TC) upon reasonable request.

\section{Ethics approval and consent to participate}

The study was approved by the National Medical Ethics Committee of the Republic of Slovenia (No. 122/05/12). Written informed consent was obtained from all patients. Adult subjects provided informed consent, and a parent or guardian of child participants provided informed consent on their behalf.

Consent for publication

Not applicable.

\section{Competing interests}

We hereby declare that we have no competing interests.

\section{Author details}

'Institute of Microbiology and Immunology, Faculty of Medicine, University of Ljubljana, Zaloška 4, SI-1000 Ljubljana, Slovenia. ${ }^{2}$ Department of Infectious Diseases, University Medical Centre Ljubljana, Japljeva 2, SI-1000 Ljubljana,

Slovenia. ${ }^{3}$ Department of Infectious Diseases, General Hospital Celje,

Oblakova ulica 5, SI-3000 Celje, Slovenia. ${ }^{4}$ Department of Infectious Diseases, General Hospital Novo Mesto, Šmihelska cesta 1, SI-5000 Novo Mesto, Slovenia. ${ }^{5}$ Department of Infectious Diseases, University Medical Centre Maribor, Ljubljanska ulica 5, SI-2000 Maribor, Slovenia. ${ }^{6}$ Department of Infectious Diseases, General Hospital Murska Sobota, Ulica dr. Vrbnjaka 6, SI-9000 Murska Sobota, Slovenia.

Received: 18 March 2019 Accepted: 4 March 2020

Published online: 11 March 2020

\section{References}

1. Levett PN. Leptospirosis. Clin Microbiol Rev. 2001;14(2):296-326.

2. Bharti AR, Nally JE, Ricaldi JN, Matthias MA, Diaz MM, Lovett MA, et al. Leptospirosis: a zoonotic disease of global importance. Lancet Infect Dis. 2003;3(12):757-71

3. Bedernjak J. Leptospiroze pri nas in v svetu. Murska sobota: Pomurska založba; 1993.

4. Levett PN. Leptospira. In: BJ MPR, Jorgensen JH, editors. Manual of clinical microbiology. 9th. Washington, D.C.: ASM Press; 2007. p. 963-70. 
5. Avsic-Zupanc T, Poljak M, Furlan P, Kaps R, Xiao SY, Leduc JW. Isolation of a strain of a Hantaan virus from a fatal case of hemorrhagic fever with renal syndrome in Slovenia. Am J Trop Med Hyg. 1994;51(4):393-400.

6. Organization WH. Human leptospirosis: quidance for diagnosis, surveillance and control. Geneva: WHO; 2003.

7. Wuthiekanun V, Chierakul W, Limmathurotsakul D, Smythe LD, Symonds ML, Dohnt MF, et al. Optimization of culture of Leptospira from humans with leptospirosis. J Clin Microbiol. 2007:45(4):1363-5.

8. Ooteman MC, Vago AR, Koury MC. Evaluation of MAT, IgM ELISA and PCR methods for the diagnosis of human leptospirosis. J Microbiol Methods. 2006;65(2):247-57.

9. Ahmed A, Engelberts MF, Boer KR, Ahmed N, Hartskeerl RA. Development and validation of a real-time PCR for detection of pathogenic leptospira species in clinical materials. PLoS One. 2009;4(9):e7093.

10. Picardeau M, Bertherat E, Jancloes M, Skouloudis AN, Durski K, Hartskeerl RA. Rapid tests for diagnosis of leptospirosis: current tools and emerging technologies. Diagn Microbiol Infect Dis. 2014;78(1):1-8.

11. Smythe LD, Smith IL, Smith GA, Dohnt MF, Symonds ML, Barnett L, et al. A quantitative PCR (TaqMan) assay for pathogenic Leptospira spp. BMC Infect Dis. 2002;2:13.

12. Stoddard RA, Gee JE, Wilkins PP, McCaustland K, Hoffmaster AR. Detection of pathogenic Leptospira spp. through TagMan polymerase chain reaction targeting the LipL32 gene. Diagn Microbiol Infect Dis. 2009;64(3):247-55.

13. Bourhy P, Bremont S, Zinini F, Giry C, Picardeau M. Comparison of real-time PCR assays for detection of pathogenic Leptospira spp. in blood and identification of variations in target sequences. J Clin Microbiol. 2011;49(6): 2154-60.

14. Thaipadungpanit J, Chierakul W, Wuthiekanun V, Limmathurotsakul D, Amornchai P, Boonslip S, et al. Diagnostic accuracy of real-time PCR assays targeting 165 rRNA and lipL32 genes for human leptospirosis in Thailand: a case-control study. PLoS One. 2011;6(1):e16236.

15. Villumsen $S$, Pedersen R, Borre MB, Ahrens P, Jensen JS, Krogfelt KA. Novel TagMan(R) PCR for detection of Leptospira species in urine and blood: pitfalls of in silico validation. J Microbiol Methods. 2012;91(1):184-90.

16. Pinne M, Haake DA. LipL32 is a subsurface lipoprotein of Leptospira interrogans: presentation of new data and reevaluation of previous studies. PLoS One. 2013;8(1):e51025.

17. Malmstrom J, Beck M, Schmidt A, Lange V, Deutsch EW, Aebersold R. Proteome-wide cellular protein concentrations of the human pathogen Leptospira interrogans. Nature. 2009;460(7256):762-5.

18. Murray GL. The lipoprotein LipL32, an enigma of leptospiral biology. Vet Microbiol. 2013;162(2-4):305-14.

19. Benoit VM, Petrich A, Alugupalli KR, Marty-Roix R, Moter A, Leong JM, et al. Genetic control of the innate immune response to Borrelia hermsii influences the course of relapsing fever in inbred strains of mice. Infect Immun. 2010;78(2):586-94.

20. Podgorsek D, Cerar T, Logar M, Lesnicar G, Remec T, Baklan Z, et al. Evaluation of the immunochromatographic (Leptocheck) test for detection of specific antibodies against leptospires. Wien Klin Wochenschr. 2015 127(23-24):948-53.

21. Exner MM, Lewinski MA. Isolation and detection of Borrelia burgdorferi DNA from cerebral spinal fluid, synovial fluid, blood, urine, and ticks using the Roche MagNA pure system and real-time PCR. Diagn Microbiol Infect Dis. 2003:46(4):235-40.

22. Merien F, Amouriaux P, Perolat P, Baranton G, Saint Gl. Polymerase chain reaction for detection of Leptospira spp. in clinical samples. J Clin Microbiol. 1992:30(9):2219-24.

23. Murgia R, Riquelme N, Baranton G, Cinco M. Oligonucleotides specific for pathogenic and saprophytic leptospira occurring in water. FEMS Microbiol Lett. 1997;148(1):27-34.

24. Werle E, Schneider C, Renner M, Volker M, Fiehn W. Convenient single-step, one tube purification of PCR products for direct sequencing. Nucleic Acids Res. 1994;22(20):4354-5.

25. Sanger F, Nicklen $S$, Coulson AR. DNA sequencing with chain-terminating inhibitors. Proc Natl Acad Sci U S A. 1977;74(12):5463-7.

26. ESG S. Epitools epidemiological calculators: Ausvet Pty Ltd; 2018 http:// epitools.ausvet.com.au. Accessed 2.2.2020.

\section{Publisher's Note}

Springer Nature remains neutral with regard to jurisdictional claims in published maps and institutional affiliations.

Ready to submit your research? Choose BMC and benefit from:

- fast, convenient online submission

- thorough peer review by experienced researchers in your field

- rapid publication on acceptance

- support for research data, including large and complex data types

- gold Open Access which fosters wider collaboration and increased citations

- maximum visibility for your research: over $100 \mathrm{M}$ website views per year

At $\mathrm{BMC}$, research is always in progress.

Learn more biomedcentral.com/submissions 